\title{
THERAPEUTIC EFFECTS OF HONEY VERSUS SILVER SULPHADIAZINE IN THE MANAGEMENT OF BURN INJURIES
}

\author{
Abdul Razzak Memon, S. M. Tahir, Imdad A. Khushk \\ and Ghulam Ali Memon
}

\begin{abstract}
OBJECTIVE: To determine the therapeutic effects of honey versus silver sulphadiazine $1 \%$ in the management of burn injuries, in our set up.

DESIGN: A quasi-experimental study.

SETTING: Burns emergency unit, department of Plastic Surgery Liaquat University Hospital, Hyderabad - Sindh form January 2002 to December 2003.

METHODS: Eighty patients having age range of 4 to 62 years with burn involving $10 \%$ to $40 \%$ body surface area were studied. Patients presenting with chemical or electric burn, and those with full thickness burn were excluded. Majority of cases was males. Patients were divided in two groups. One group received treatment with honey while other received silver sulphadiazine. Honey used was natural and unprocessed.

RESULTS: Patients treated with honey showed rapid wound healing with no apparent local or systemic side effects. Mean duration of healing in honey treated group was 15.3 days. While in other group, mean was 20 days. Patients treated with honey did not develop growth of any pathogenic organism. However, $32(80 \%)$ patients treated with silver sulphadiazine showed growth of different pathogenic organisms necessitating the use of systemic antibiotic therapy accordingly. In honey group, only $3(7.5 \%)$ patients developed contracture as compared to $\mathbf{7}(\mathbf{1 7 . 5 \% )}$ patients treated with silver sulphadiazine. After complete healing, itching/pruritus was complained by $13(32.5 \%)$ patients treated with silver sulphadiazine while only $2(5 \%)$ patients complained so treated with honey.

CONCLUSION: The burn wounds are healed rapidly by using honey with minimum scarring and pigmentation as compared to silver sulphadiazine. Use of honey in these patients can be cost effective in terms of treatment and hospital stay. However, to develop more confidence with the use of honey in burn wound management, more studies with larger sample size are needed.
\end{abstract}

KEY WORDS: Burn. Honey. Silver Sulphadiazine. Management. Pakistan.

\section{INTRODUCTION}

Burn comprises of a spectrum of injury, severity depending on the depth of wound and the proportion of body area affected. Burn may be defined as "coagulative destruction of the surface layers of the body caused by heat, chemicals or irradiation". The depth of burn can be assessed clinically by its different characteristics such as color, capillary refill, sensation, blisters and healing. Silver sulphadiazine $1 \%$ has been commonly used in burn wound management since 1968 to try to overcome the problem of infection. ${ }^{1-3}$ This is a broad spectrum antimicrobial agent, having long half life, almost no systemic absorption and claim to retain its activity in the presence of pus. Though, honey is being used in traditional medicine since 2000 B.C, however, recently published reports showing its marked therapeutic effects in modern medicine have rekindled interest in its use in burn and wounds. ${ }^{4-8}$ Honey is one of the oldest sweeteners known to man. Many definitions 
and standards have been used to describe honey, although few, if any, are complete. One of the better definitions defines honey as a 'sweet, viscous fluid elaborated by bees from the nectar of plants and stored in their combs as food'. Honey is composed mainly of a variety of sugars, traces of pollen and water. There are also enzymes present. Composition of honey ${ }^{9}$ is shown in Table I. Honey has several important qualities in addition to composition and taste. The low moisture content in honey is one of its most important characteristics as it influences keeping quality, rate of granulation and body (Granulation is said to occur when dextrose, a major sugar in honey can spontaneously crystallize from any honeys in the form of its monohydrate. This sometimes occurs when the moisture level in honey is allowed to drop below a certain level). Honey is hygroscopic (absorbs moisture) and remove moisture from the air if the relative humidity exceeds $60 \%$. Care must be taken in the handling and storage of honey to be sure that this does not happen. The low moisture content of honey also forms an important part of the system which protects honey from attack by microorganisms. Honey's hyperosmotic nature (due to the high concentration of solids and low moisture content) prevents the growth of bacteria and yeasts as it draws water out of the organisms, killing them by desiccation. The high acidity of honey also plays an important role in the system, which prevents bacterial growth. The $\mathrm{pH}$ of honeys may vary from approximately 3.2 to 4.5 (average $\mathrm{pH}=3.9$ ) making it inhospitable for attack by most bacteria. Finally, honey is an antibacterial of inhibine system. Bees add an enzyme glucose oxidase to honey and this enzyme reacts with glucose to produce hydrogen peroxide and gluconic acid, both of which have an antibacterial effect. ${ }^{10,11}$ Such properties of honey appear to be an ideal agent in the management of burn injuries as it is natural, low cost, easily available and lacks systemic side effects associated with the use of silver sulphadiazine $1 \%$ like fever neutropenia, pigmentation and local sepsis. Therefore, we designed this study in order to compare the therapeutic effects of honey with silver sulphadiazine $1 \%$ in our set up.
TABLE I:

COMPOSITION OF 100 GRAMS OF HONEY (312 KILOCALORIES)

\begin{tabular}{|l|l|}
\hline \multicolumn{1}{|c|}{ CONSTITUENT } & \multicolumn{1}{c|}{ AMOUNT } \\
\hline Fructose & $38.50 \mathrm{gm}$ \\
\hline Glucose & $31.00 \mathrm{gm}$ \\
\hline Water & $17.10 \mathrm{gm}$ \\
\hline Maltose & $7.20 \mathrm{gm}$ \\
\hline Sucrose & $1.50 \mathrm{gm}$ \\
\hline Thiamin & $<0.006 \mathrm{mg}$ \\
\hline Riboflavin & $<0.06 \mathrm{mg}$ \\
\hline Niacin & $<0.36 \mathrm{mg}$ \\
\hline Pantothenic acid & $<0.11 \mathrm{mg}$ \\
\hline Pyridoxine & $<0.32 \mathrm{mg}$ \\
\hline Ascorbic acid & $2.2-2.4 \mathrm{mg}$ \\
\hline Enzymes & $\begin{array}{l}\text { Invertase, Diastase }, \\
\text { Glucose oxidase }\end{array}$ \\
\hline Calcium & $4.40-9.20 \mathrm{mg}$ \\
\hline Copper & $0.003-0.10 \mathrm{mg}$ \\
\hline Iron & $0.06-1.50 \mathrm{mg}$ \\
\hline Magnesium & $1.20-3.50 \mathrm{mg}$ \\
\hline Maganese & $0.02-0.40 \mathrm{mg}$ \\
\hline Phosphorus & $1.90-6.30 \mathrm{mg}$ \\
\hline Potassium & $13.20-168.00 \mathrm{mg}$ \\
\hline Sodium & $0.00-7.60 \mathrm{mg}$ \\
\hline Zinc & $0.03-0.40 \mathrm{mg}$ \\
\hline Trace elements, & Present \\
\hline Nitrogen, Acids & \\
\hline & \\
\hline
\end{tabular}

\section{PATIENTS AND METHODS}

Burns Emergency Unit at Liaquat University Hospital, Hyderabad was established in April 2001. Being largest burn centre in Sindh after Karachi has large turnover of patients. A total of 80 patients (54 males and 26 females) were enrolled for this study. Inclusion criteria was burn with $10 \%$ to $40 \%$ body surface area (BSA), age range 4 to 62 years and dermal burn that includes superficial dermal, mid dermal and deep dermal as assessed clinically. Meanwhile, patients presenting with superficial burn 
(Erythema), with chemicals or electric burn, those with full thickness burn as assessed clinically and patients with more than $40 \%$ BSA involved were excluded. Complicated burn cases for example, patients in addition to burn also had hypertension, diabetes mellitus and pregnancy were also excluded. The informed consent was obtained from the patients. The patients were allotted at random into two different groups. Distribution of patients managed with honey and silver sulphadiazine, with respect to BSA burn in $\%$ and depth of burn as assessed clinically is shown in Tables II and III respectively. The systemic management for patients of both groups was identical as was the initial resuscitation. Honey use was natural and unprocessed. The burn wound was washed with normal saline and povidide-lodine, covered with cotton gauze. A tailor made dressing having $5 \mathrm{~mm}$ thick medical grade cotton was placed in between two layers of gauze cloth after applying about $3 \mathrm{~mm}$ thick layer of honey. For patients of other group, affected area was washed similarly and wound was closed with occlusive dressing after applying $3 \mathrm{~mm}$ thick layer of silver sulphadiazine. For both groups, dressings were changed on alternate day basis. Swab cultures for sensitivity were sent on admission day, day 5 , day 15 , and day 25 for patients of both groups.

TABLE II:

BODY SURFACE AREA INVOLVEMENT IN PATIENTS TREATED WITH HONEY AND SILVER SULPHADIAZINE

\begin{tabular}{|c|c|c|}
\hline $\begin{array}{c}\text { BODY SUR- } \\
\text { FACE AREA \% }\end{array}$ & $\begin{array}{c}\text { HONEY } \\
\text { GROUP (n=40) }\end{array}$ & $\begin{array}{c}\text { SILVER SUL- } \\
\text { PHADIAZINE } \\
\text { GROUP (n=40) }\end{array}$ \\
\hline $10-15 \%$ & 18 & 12 \\
\hline $16-25 \%$ & 14 & 20 \\
\hline $26-40 \%$ & 8 & 8 \\
\hline
\end{tabular}

TABLE III:

DEPTH OF BURN IN PATIENTS TREATED WITH HONEY AND SILVER SULPHADIAZINE

\begin{tabular}{|l|c|c|}
\hline \multicolumn{1}{|c|}{ DEPTH OF BURN } & $\begin{array}{l}\text { HONEY } \\
\text { GROUP }\end{array}$ & $\begin{array}{c}\text { SILVER SUL- } \\
\text { PHADIAZINE } \\
\text { GROUP }\end{array}$ \\
\hline Superficial dermal burn & 18 & 12 \\
\hline Mid dermal burn & 6 & 8 \\
\hline Deep dermal burn & 16 & 20 \\
\hline
\end{tabular}

\section{RESULTS}

Patients treated with honey showed rapid wound healing with no apparent local or systemic untoward side effects attributable to the use of honey. Of 40 patients treated with honey, complete healing occurred in 20(50\%) patients by day 16 and by day 26 in $12(30 \%)$ patients (Table IV). Meanwhile, $8(20 \%)$ patients completely healed by day 30 (Mean 15.3 days). However, in other group treated with silver sulphadiazine, mean duration of healing was 20 days. In $16(40 \%)$ patients complete healing occurred by day 20 , in $18(45 \%)$ patients it was by day 36 and $6(15 \%)$ recovered completely by day 46 (Table V). The sensitivity results of swabs taken from wounds of these patients revealed that all patients treated with honey did not show growth of any pathogenic organism. On the other hand, $32(80 \%)$ patients of other group showed growth of different pathogenic organisms during their treatment and therefore, necessitating the use of systemic antibiotic therapy accordingly (Table VI). All these patients were closely followed up regularly after being discharged from the hospital. However, post-burn contracture developed in 10 patients (Table VII). Among these, only 3(7.5\%) patients were those who were treated with honey while $7(17.5 \%)$ patients were from silver sulphadiazine group. Olive oil massage, compressive bandages and physiotherapy were advised to all of them. Surprisingly, all patients belonging to honey group responded well to these conservative measures while with silver sulphadiazine only 3 patients responded to the conservative measures. Four patients who did not respond to conservative measures underwent surgery; by release of contracture and skin grafting to correct the deformity. After complete healing of the burn injuries, other common complains observed were pruritus/itching at healed area, pigmentation/hypopigmentation and recurrent minor breaks/breaches at scarred/healed area. All patients of this series were closely followed up for such complains. Itching I pruritus was complained by 13 patients of silver sulphadiazine group while only 2 patients complained of so treated with honey. On the other hand, hypopigmentation was seen in 2 patients treated with honey and hyper-pigmentation was seen in 10 patients treated with silver sulphadiazine. The frequency of minor skin breaks/breaches was also slightly higher in silver sulphadiazine group (5 patients in honey group and 7 in silver sulphadiazine group). 
TABLE IV:

HEALING RESPONSE IN DAYS AND DEPTH OF BURN IN PATIENTS TREATED WITH HONEY $(n=40)$

\begin{tabular}{|l|c|c|c|}
\hline \multicolumn{1}{|c|}{ Day } & $\mathbf{1 6}$ & $\mathbf{2 6}$ & $\mathbf{3 0}$ \\
\hline $\begin{array}{l}\text { Superficial dermal } \\
\text { burn }\end{array}$ & $18(45 \%)$ & & \\
\hline Mid dermal burn & $2(5 \%)$ & $4(10 \%)$ & \\
\hline Deep dermal burn & & $8(20 \%)$ & $8(20 \%)$ \\
\hline TOTAL & $20(50 \%)$ & $12(30 \%)$ & $8(20 \%)$ \\
\hline
\end{tabular}

TABLE V:

HEALING RESPONSE IN DAYS AND DEPTH OF BURN IN PATIENTS TREATED WITH SILVER SULPHADIAZINE $(n=40)$

\begin{tabular}{|l|c|c|c|}
\hline \multicolumn{1}{|c|}{ Day } & $\mathbf{2 0}$ & $\mathbf{3 6}$ & $\mathbf{4 6}$ \\
\hline $\begin{array}{l}\text { Superficial dermal } \\
\text { burn }\end{array}$ & $12(30 \%)$ & & \\
\hline Mid dermal burn & $4(10 \%)$ & $4(10 \%)$ & \\
\hline Deep dermal burn & & $14(35 \%)$ & $6(15 \%)$ \\
\hline TOTAL & $16(40 \%)$ & $18(45 \%)$ & $6(15 \%)$ \\
\hline
\end{tabular}

TABLE VI:

PATHOGENIC ORGANISMS SEEN IN CASES TREATED WITH SILVER SULPHADIAZINE $(n=40)$

\begin{tabular}{|l|c|}
\hline \multicolumn{1}{|c|}{ Organism } & Number of Cases (\%) \\
\hline Staph. Aureus & $14(35)$ \\
\hline Pseudomonas & $7(17.5)$ \\
\hline E.Coli & $5(12.5)$ \\
\hline Citrobacter & $3(7.5)$ \\
\hline Klebsella & $3(7.5)$ \\
\hline
\end{tabular}

TABLE VII:

NUMBER OF PATIENTS WHO DEVELOPED CONTRACTURE

\begin{tabular}{|l|c|c|}
\hline $\begin{array}{c}\text { CONTRACTURE } \\
\text { SITE }\end{array}$ & $\begin{array}{c}\text { HONEY } \\
\text { GROUP } \\
(\mathbf{n = 4 0 )}\end{array}$ & $\begin{array}{c}\text { SILVER SUL- } \\
\text { PHADIAZINE } \\
\text { GROUP (n=40) }\end{array}$ \\
\hline Neck & 1 & 3 \\
\hline Axilla & 2 & 1 \\
\hline $\begin{array}{l}\text { Interphalangeal } \\
\text { joints }\end{array}$ & - & 2 \\
\hline Popliteal fossa & - & 1 \\
\hline Total & 3 & 7 \\
\hline
\end{tabular}

\section{DISCUSSION}

The major problems associated with burn injury are the rate of healing and quality of resultant scar. These persist; yet, great advances in the management of burn injury have been made and search for an ideal burn wound dressing continues. The findings of this study have shown that accelerated rate of wound healing with good quality scar without hyperpigmentation is successfully achieved in patients treated with honey. The results of this study are consistent with that of other studies. ${ }^{7,12,13}$ All patients treated with honey remain uninfected as shown by repeated negative swab cultures in this study. Another common complication of post-burn healing is the contracture formation. This was found to be minimal in patients treated with honey probably because of shorter healing time with resultant early mobilization. These all facts help in reducing the cost of management, hospital stay and decrease the morbidity. The acceptance of honey by patients as burn ointment was also found excellent probably as its healing properties are also mentioned in the Holy Book of Muslims. However, this study was conducted on small number of patients and to develop more confidence with the use of honey in burn wound management, more studies with large sample size and advance statistical analysis are needed. If honey reproduces consistent results in burn wound management then it is likely to be accepted in modern medicine as well.

\section{REFERENCES}

1. Jones SM, Gilbert PM. Immediate care of burn patients. Surgery International 2002; 58:125-130.

2. Lawrence CJ. A century after Gamgee. Burns Incl Therm Inj 1987; 13: 77-9.

3. Queen D, Evans JH, Gaylor JD, et al. Burn wound dressings: a review. Burn Incl Therm Inj 1987; 13:218-28.

4. Cooper RA, Molan PC, Harding KG. Antibacterial activity of honey against strains of Staphylococcus aureus from infected wounds. J R Soc Med 1999; 92:283-5.

5. Cooper RA, Molan PC. Honey in wound care. J Wound Care 1999;8(7):340.

6. Karayil S, Deshpande SD, Koppikar GV. Effect of honey on multi-drug resistance organism and its synergistic action with three common antibiotics. J Postgrad Med 1998; 44:93-6. 
7. Subrahmanyam M, Hemmady A, Pawar SG. Antibacterial effects of honey on bacteria isolates from wounds. Ann Burns Fire Disasters 2001; 14:22-2.

8. Subrahmanyam M, Shahapure AG, Nagane NS. Effects of tropical application of honey on burn wound healing. Ann Burns Fire Disasters 2001;14:142-5.

9. Reithof ML, Subers $\mathrm{MH}$ and Kushnir I. Composition of American honeys. US Dept. of Agriculture Technical Bulletin 1261.1962:124.
10. White JW Jr. Honey. In: Grout RA ed. The hive and the honey bee. Dadant and Sons Inc., Hamilton, III. 1975, p. 491-530.

11. Composition and physical properties of honey. In: Crane F ed., Honey Review. Heinemann, London, 1975 p. 157-239.

12. Tovery F. Honey and sugar as a dressing for wounds and ulcer (Editorial). Trop Doct 2000; 30:1.

13. Namias N. Honey in the management of infections. Surg Infect 2003; 4(2):219-26.

AUTHOR AFFILIATION:

Dr. Abdul Razzak Memon (Corresponding Author)

Associate Professor

Department of Plastic Surgery

Liaquat University of Medical and Health Sciences

(LUMHS), Jamshoro - Sindh.

Dr. S. M. Tahir

Assistant Professor

Department of Plastic Surgery, LUMHS Jamshoro.

Dr. Imdad A. Khushk

Senior Research Officer

Medical Research Centre, LUMHS Jamshoro.

Prof. Ghulam Ali Memon

Dean Faculty of Surgery and Allied Sciences

LUMHS Jamshoro. 